\title{
DIGITAL THERAPEUTICS IN ONCOLOGY: FINDINGS, BARRIERS AND PROSPECTS. A NARRATIVE REVIEW
}

\author{
G. Gussoni ${ }^{1}$, E. Ravot ${ }^{2}$, M. Zecchina², G. Recchiaa ${ }^{3,4}$, E. Santoro ${ }^{5}$, R. Ascione ${ }^{2}$, \\ F. Perrone ${ }^{6}$ \\ ${ }^{1}$ Research Department, FADOI Foundation, Milan, Italy \\ 2 Healthware Group, Milan and Salerno, Italy \\ ${ }^{3}$ Smith Kline Foundation, Verona, Italy \\ ${ }^{4}$ daVi DigitalMedicine, Verona, Italy \\ ${ }^{5}$ Laboratory of Medical Informatics, Mario Negri Institute for Pharmacological Research IRCCS, Milan, Italy \\ ${ }^{6}$ Clinical Trials Unit, IRCCS National Cancer Institute Fondazione Pascale, Naples, Italy
}

\section{CORRESPONDING AUTHOR:}

Gualberto Gussoni

Research Department, FADOI Foundation

Piazza Cadorna 15

20183 Milan, Italy

E-mail gualberto.gussoni@gmail.com

ORCID: 0000-0003-3573-5069

Doi: $10.48286 / a r o .2022 .39$

History

Received: Nov 14, 2021

Accepted: Jan 31, 2022

Published: Mar 1, 2022

\begin{abstract}
Digital therapeutics (DTx) have been defined as technologies that "offer therapeutic interventions driven by high-quality software programs, based on scientific evidence obtained through methodologically rigorous confirmatory clinical investigation, to prevent, manage and treat a broad spectrum of physical, mental and behavioural conditions". DTx products are on the market in a number of countries or under development for a broad range of physical and behavioral conditions, including oncology treatment management. The aim of this narrative review is to provide an update on findings available for DTx, specifically developed for the treatment of patients with cancer. A search was conducted using the following databases: PubMed, Google Scholar, Clinicaltrials.gov and Deutsches Register Klinischer Studien, as well as some websites specifically concerned with DTx.
\end{abstract}

The products included in this review had to rely on at least one randomized controlled trial (already published or ongoing); or to be in the active phase of development for oncological indications, as documented by registered ongoing clinical trials and declared by the developer ("candidate DTX").

A total of nine DTx have been selected for this review, eight of them validated by Regulatory Authorities. The mechanism of action of DTx in oncological indications is mainly linked to cognitive behavioral stress management or management of symptoms and adverse events from anti-cancer treatments. In the majority of cases, quality of life, control of fatigue and physical activity/performance status were the primary endpoints of the studies. Survival was assessed in 3 studies, showing significant benefit in cancer patients using DTx. 
Data available in the literature seem to indicate the prospect of a useful role for DTx in addressing many unmet needs that characterize the current management of cancer patients. The success of this path is linked to a series of significant aspects: need for more clinical research and evidence of

\section{KEY WORDS}

Digital therapeutics; oncology; clinical validation; behavior; patient-reported outcomes. clinical benefit on relevant outcomes; greater improved familiarity of physicians with these technologies, regulatory systems ready to evaluate the products, possibly also for reimbursement; and access to technology, together with improved digital literacy, for patients and caregivers.

\section{IMPACT STATEMENT}

Digital therapeutics are evidence-based devices aimed at interacting with the patient, and offer potential benefits for patients with cancer (reduced symptom distress, improved medication adherence, adverse event management, quality of life and survival).

\section{INTRODUCTION}

Digital therapeutics (DTx) have been defined as technologies that "offer therapeutic interventions driven by high-quality software programs, based on scientific evidence obtained through methodologically rigorous confirmatory clinical investigation, to prevent, manage and treat a broad spectrum of physical, mental and behavioural conditions" $(1,2)$. The key aspects to note in this definition of DTx are: (i) high-quality software programs; (ii) confirmatory evidence-based investigation; and (iii) therapeutic interventions. These distinguish DTx from other digital health products such as digital wellness apps, the various forms of software or hardware used to obtain measurements that could be useful for health purposes, or the socalled digital pills (i.e. pharmaceuticals with an integrated sensor that is activated once the drug arrives in the digestive tract, triggering a signal to an app housed on a smartphone in order to indicate that the treatment has been taken as prescribed).

Recognizing that DTx must be "confirmatory trial evidence-based" is crucial. Since the purpose of DTx is to obtain a clinically relevant effect, and a likely scenario for their place in therapy is that of a medical prescription, it seems reasonable to require that their prescription for a certain therapeutic indication is based on an experimental clinical validation comparable to that of other therapeutic products (e.g. a drug) prescribable for the same indication. In this perspective, various institutions have been working toward developing a standard for determining how much evidence is required to go to market or what type of evidence and regulation is needed (3).

While drug treatment interacts with the patient's biology,

the main mechanism by which DTx achieve the therapeutic effect is through interaction with patients' thoughts, and correction of dysfunctional behaviors. In this perspective, another peculiar characteristic of DTx emerges, namely the active and participative involvement of the patient and/or caregiver, which is crucial to the success of the treatment pathway. As part of this pathway, DTx can work in a standalone modality, or in association / combination with drugs and other active treatment measures for the target pathology/clinical condition (4).

For illustrative purposes, we can propose an analogy between DTx and drugs. Looked at in these terms, a DTx product, which can take such different forms as an app (on a smartphone or tablet), a video game or a virtual reality system, may comprise an active principle and one or more excipients. Whereas in classical pharmacology the active principle is a chemical or biological molecule, in DTx it is the algorithm that constitutes the active element responsible for the clinical effect, whether positive (clinical benefit) or negative (undesired effects).

With regard to the discovery of the active principle, we have at least two main options:

- use a treatment already available in the scientific literature (e.g., a tried and tested cognitive behavioral therapy), affording an alternative to administration of a known treatment;

- use a newly developed active principle, for instance, by setting up an original combination of different treatment modalities (e.g., cognitive behavioral therapy, motivational interviewing, psychoeducation, etc.), based on the experience of the patient, the caregiver, the 
medical specialist and the team of developers working on the algorithm.

As is the case with traditional drugs, the aim of the excipient is to "give shape" to the active principle and enable the patient to take it, making it as bioavailable - or, in this case, digitally bioavailable - as possible; for this purpose, reward and/or gamification modules introduce an element of patient gratification or of gaming into the dynamics of user interaction with the system. There may also be reminders to the patients that they must take the DTx product and complementary therapies, as well as modules to put them in touch with the physician and with other patients following the same therapeutic indication. The excipients can also include the user interface, which plays a fundamental role in making the therapy acceptable, ensuring patient compliance and, as a result, securing the expected therapeutic outcome (5). In addition, just like conventional drugs, DTx also have a well-defined indication and posology, which clearly differentiate them from digital health apps targeting consumers (not patients). Today, DTx products are on the market or under de- velopment for a broad range of physical and behavioral conditions (mostly chronic) such as diabetes, anxiety disorder, depression, insomnia, attention-deficit/ hyperactivity disorder (ADHD), substance use disorder, hypertension, chronic obstructive pulmonary disease, and oncology treatment management (6). To have a quantitative idea of the research focused on these products and examine its geographical distribution, we explored the ClinicalTrials.gov register. By searching the strings "digital therapeutic OR digital therapy" in the "Intervention/treatment" field (January 17, 2022), we found 360 ongoing clinical studies in the area of DTx. As documented by a recent systematic review (7), however, it is important to note that these figures could be significantly overestimated as a result of misclassification, since product characteristics and study aims in many cases are not consistent with the above-mentioned definition of "digital therapeutics". Figure 1 shows the geographical distribution of these ongoing studies, which are mainly based in North America (57\%), followed by Europe (31\%) and China (6\%).

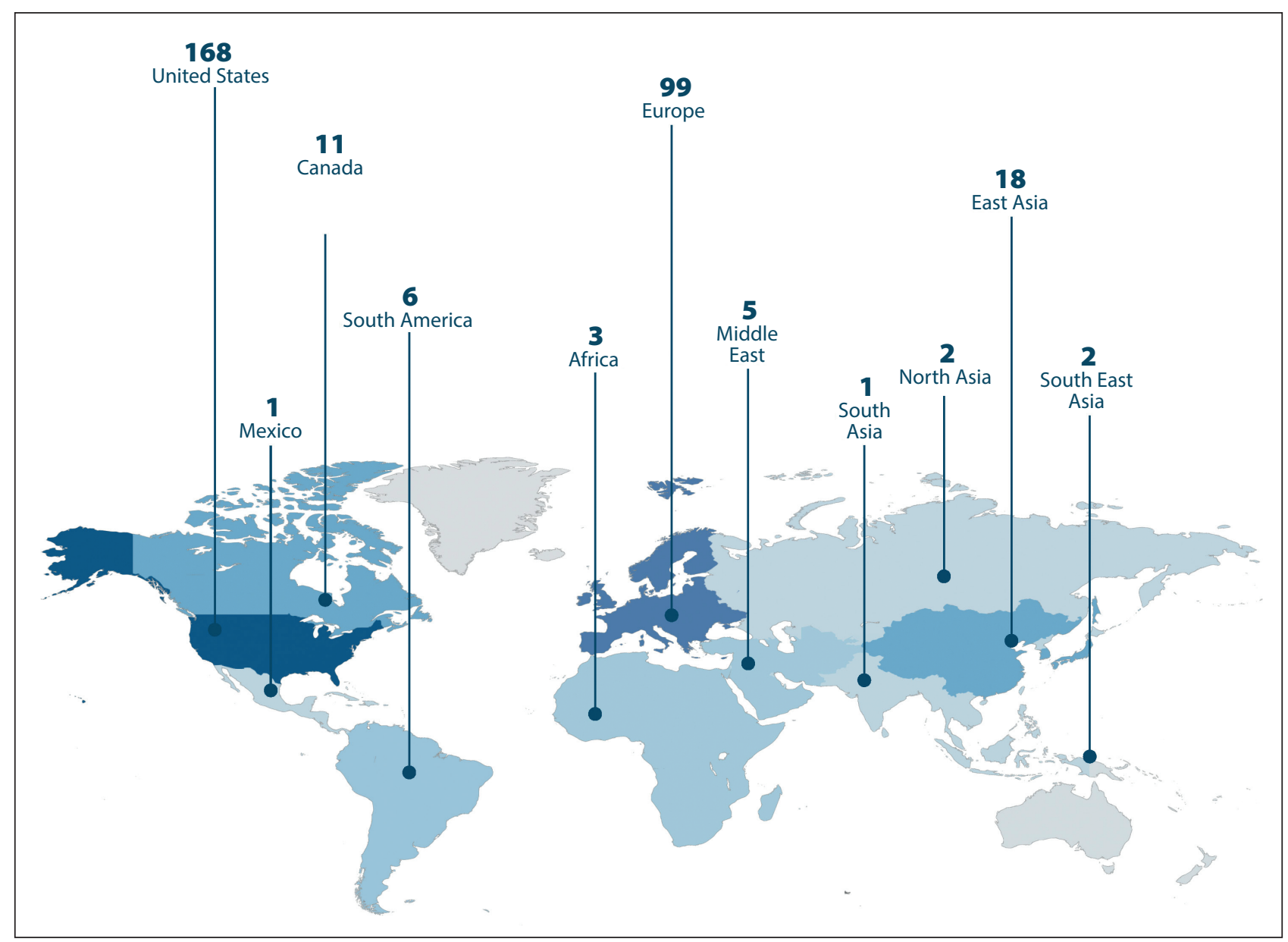

Figure 1. Overview of geographical distribution of ongoing clinical trials in digital therapeutics* (source ClinicalTrials.gov).

*Studies with no locations are not included in the counts on the map.

Studies with multiple locations are included in each region containing locations. 


\section{CANCER AND DTx}

A global surveillance report suggests a trend toward increased survival for patients with cancer (8), with some tumors becoming increasingly chronic. The recent intensive development of therapies with novel mechanisms of action, including molecular targeted therapies, immuno-oncology therapies, and precision radiation oncology, has transformed the treatment landscape for cancer (9-11). These advances have increased the complexity of treatment (e.g., combination of therapies) and required modifications in the patient pathway to ensure quality care. More drugs are available in oral formulations for home administration, with reduced face-to-face surveillance by healthcare professionals, and a greater likelihood of non-adherence and administration errors by patients (12); further, the prolonged use of such treatments as long-term maintenance may be associated with the emergence of toxicities (13). Additionally, a potential shortage in oncology services and workforce, linked to increasing cancer incidence and complexity of cancer treatments (14) has highlighted the need for new strategies to ensure that all patients receive optimal treatment and care throughout the continuum of disease, while also enhancing their ability to manage symptoms and treatment-related side effects. The new approaches should focus on patient-centred care, with integration of tumor-directed treatment alongside patient-directed support- ive and palliative care throughout the disease journey $(15,16)$ (figure 2 ). The goals of management are to achieve improvements not only in overall survival (OS) but also in patient-reported outcomes (PROs), such as quality of life (QoL) (17), fewer emergency department visits, and self-reported improvements of symptoms $(17,18)$. Finally, since the total burden of new cancer cases is increasing, and new therapies are generally more expensive (19), novel approaches for optimal patient management allowing containment of healthcare costs are needed (20).

All these aspects underpin a strong rationale for an increasingly integrated approach to the management of cancer patients, embracing contributions from health products of various kinds, such as digital solutions, and with the aim of supporting both physical and mental health.

Digital health technologies for people with cancer include mobile apps for pain relief (21), self-management $(22,23)$, or videogames designed to promote physical exercise and mental empowerment in pediatric oncology patients $(24,25)$. Personalized digital interventions for oncology patients, with scope for provision of diverse self-care modalities such as physical exercises, yoga, mindfulness meditations and breathing exercises, can support anti-cancer therapies. Potential benefits of these interventions also include reduced symptom distress, decreased unplanned hospitalizations, as well as improved medication adherence, adverse event

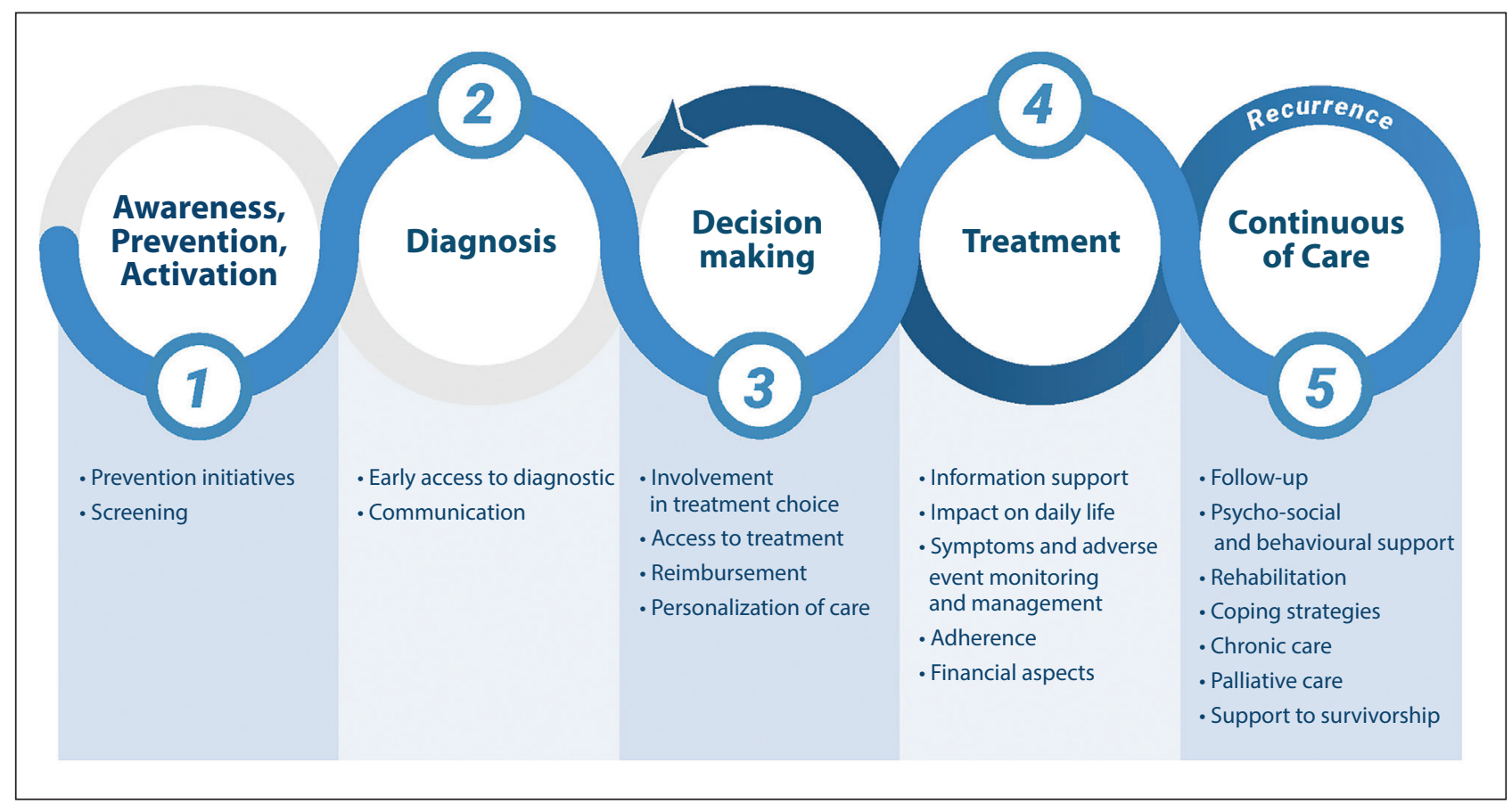

Figure 2. Illustrative example of Patient Journey in oncology, with relevant touchpoints $(15,16)$. 
management, quality of life and survival (11). Among patients receiving treatment for advanced cancers, symptoms are common and frequently cause distress, functional impairment, emergency room visits and hospitalizations (26). Yet cancer patients' symptoms often go undetected and unaddressed by clinicians (27-29). Digital therapeutics are evidence-based medical devices, in which the active principle is represented by an algorithm/software (Software as a Medical Device - SaMD): this interacts with the patient by providing behavioral indications, collecting real-time data and clinical information which can be shared with the healthcare personnel and, if needed, favor timely therapeutic interventions. There is growing interest in integrating healthcare solutions such as DTx into routine practice for the management of chronic diseases, and the aim of this narrative review is to provide an update on the findings available for digital products classifiable as DTx on the basis of the above definition, and specifically developed for the treatment of patients with cancer. In many countries across the world, numerous other available DTx can be prescribed to cancer patients for the management of accompanying clinical conditions (e.g. depression, insomnia, abuse of opioids etc.): these products have not been considered for the purposes of this review.

\section{METHODS}

The MEDLINE Public Library of Medicine (PubMed) and Google Scholar databases were explored in the period September 2021-January 2022, for relevant studies published in the previous five years, and using the following search terms: (i) MEDLINE: digital therapies AND cancer; digital ther ${ }^{*}$ AND (cancer OR oncology OR tumor OR neoplasm OR carcinoma); digital therapeutics AND leukemia; digital therapeutics AND lymphoma; (ii) Google Scholar (allintitle): digital therapeutics; digital therapeutics cancer; digital therapeutics tumor; digital therapeutics cancer approved; digital therapy cancer. Focused or selective searches were also performed on: (i) databases of clinical studies, in particular Clinicaltrials.gov and Deutsches Register Klinischer Studien (DRKS); (ii) websites or reports with a specific focus on DTx, in particular: BfArM/DiGa directory, Digital Therapeutics Alliance, daVinci Digital Therapeutics, Digital Therapeutics in the Oncology Market, and company websites of individual DTx. Randomized controlled trials, observational studies, feasibility or pilot studies, editorials and reviews that evaluated efficacy/safety or effectiveness of DTx products in cancer patients were eligible for inclusion. Descriptions of the design of ongoing or planned studies available through the clinical studies databases or other sources were also considered. Search results were critically analysed by the authors for relevance to the focus of this review (figure 3).

The products included in this review and classified as DTx had to rely on at least one randomized controlled trial with confirmatory characteristics (already published or ongoing) ("DTx"); or to be in active phase of development for oncological in-

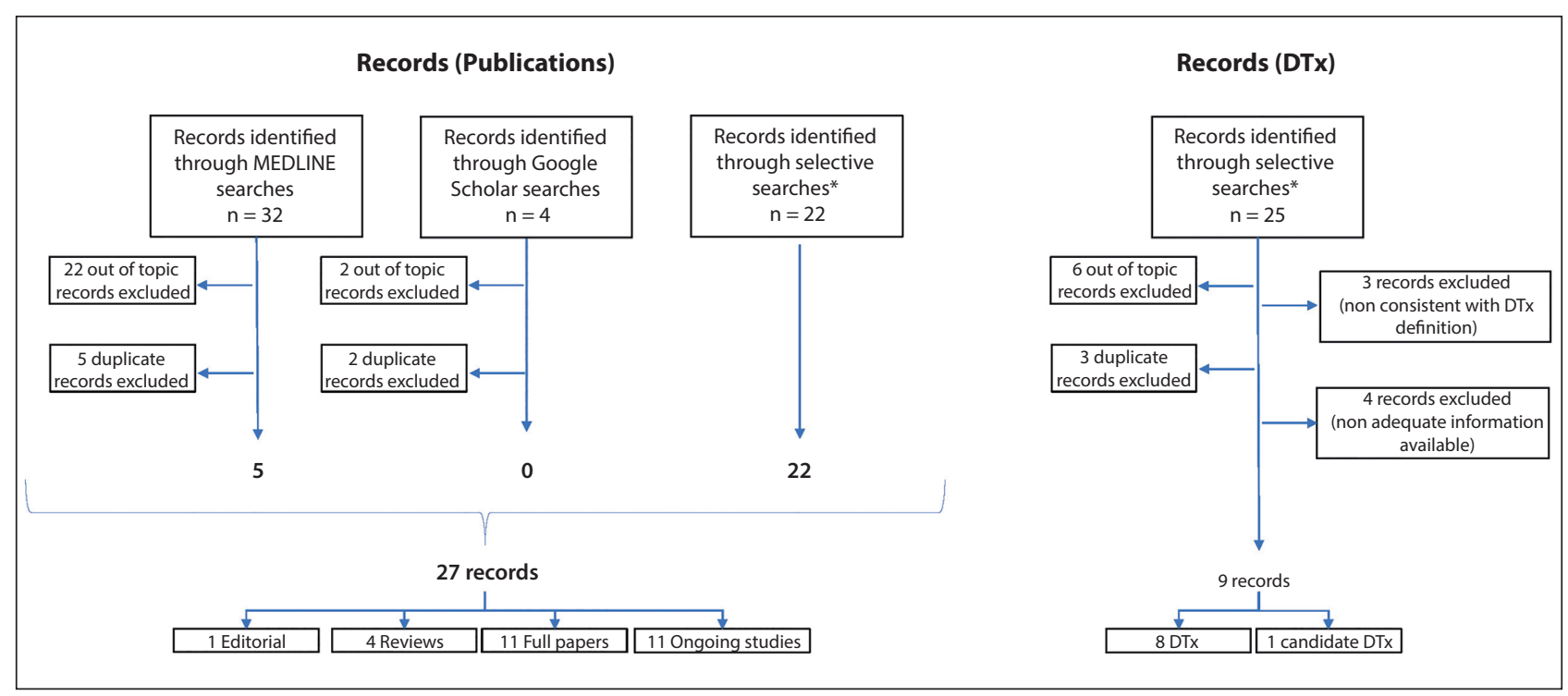

Figure 3. Flowchart of methods and related results.

*Clinicaltrials.gov (https://clinicaltrials.gov/), DRKS, BfArM/DiGa directory, ASCO Congress, Digital Therapeutics Alliance, daVinci Digital Therapeutics, Digital Therapeutics in Oncology Market and websites of Companies developing DTx. 
dications, as documented by registered ongoing clinical trials and declared by the developer ("candidate DTx") $(30,31)$.

\section{RESULTS}

The main characteristics of 11 full papers reporting the results obtained with a total of 6 DTx in patients with cancer are summarized in table I $(17,18,32$ 40). This list of papers includes controlled clinical trials $(17,18,32,33,35-37,40)$ or other types of studies, if they refer to products for which at least one randomized clinical trial was available in the literature, as additional findings contributing to their profile $(34,38,39)$. Some papers $(17,18,32$, 33) refer to more than one product since they were based on the application of a web-based platform for symptom monitoring that was used for the development of digital tools by different companies. Generally speaking, the mechanism of action of DTx in oncological indications is mainly linked to cognitive behavioral stress management or management of symptoms and possible adverse events of anti-cancer treatments. In a couple of these studies, products' feasibility of use and ability to engage the patients were specifically addressed; in one of them, the attitude of healthcare professionals towards DTx, the integration of this technology into the clinical workflow and the opportunity for saving time by decreasing phone consultations and visits were indirectly evaluated (interviews/questionnaires). In the majority of cases, QoL was the primary endpoint of the study, together with die- tary habits and physical activity/performance status. The study that enrolled the highest number of patients was specifically aimed at improvements in fatigue severity and reduction of fatigue interference with daily activities. Survival was assessed in 3 studies, showing significant benefit in cancer patients using DTx. Further, in one study patients receiving the digital intervention were able to tolerate continuation of chemotherapy longer than when receiving usual care (mean 8.2 vs 6.3 months, $p=0.002$ ) (17). Finally, preliminary findings indicate a potential benefit of DTx in terms of healthcare organization and costs, by decreasing the need for phone consultations and visits.

Our search identified the design of a number of planned or ongoing studies concerning DTx or candidate DTx in oncology. Table II summarises 5 studies registered in the ClinicalTrials.gov database, 4 studies registered in the German clinical trial database (DRKS-BfArM/DiGA directory), and 2 presented at the 2020 ASCO (American Society of Clinical Oncology) Congress. This list includes both intervention and observational studies aimed at evaluating health status (complaints/symptoms, cancer-related distress, adverse events, QoL, disease progression and survival) as well as identification of promoters and barriers to implementation of DTx in clinical practice (41-51).

Figure 4 provides an overview of worldwide regulatory status for 8 DTx products selected according to the previously described criteria and specifically developed for cancer, with their indications and main areas of intervention. Further details on this topic are given in table III.

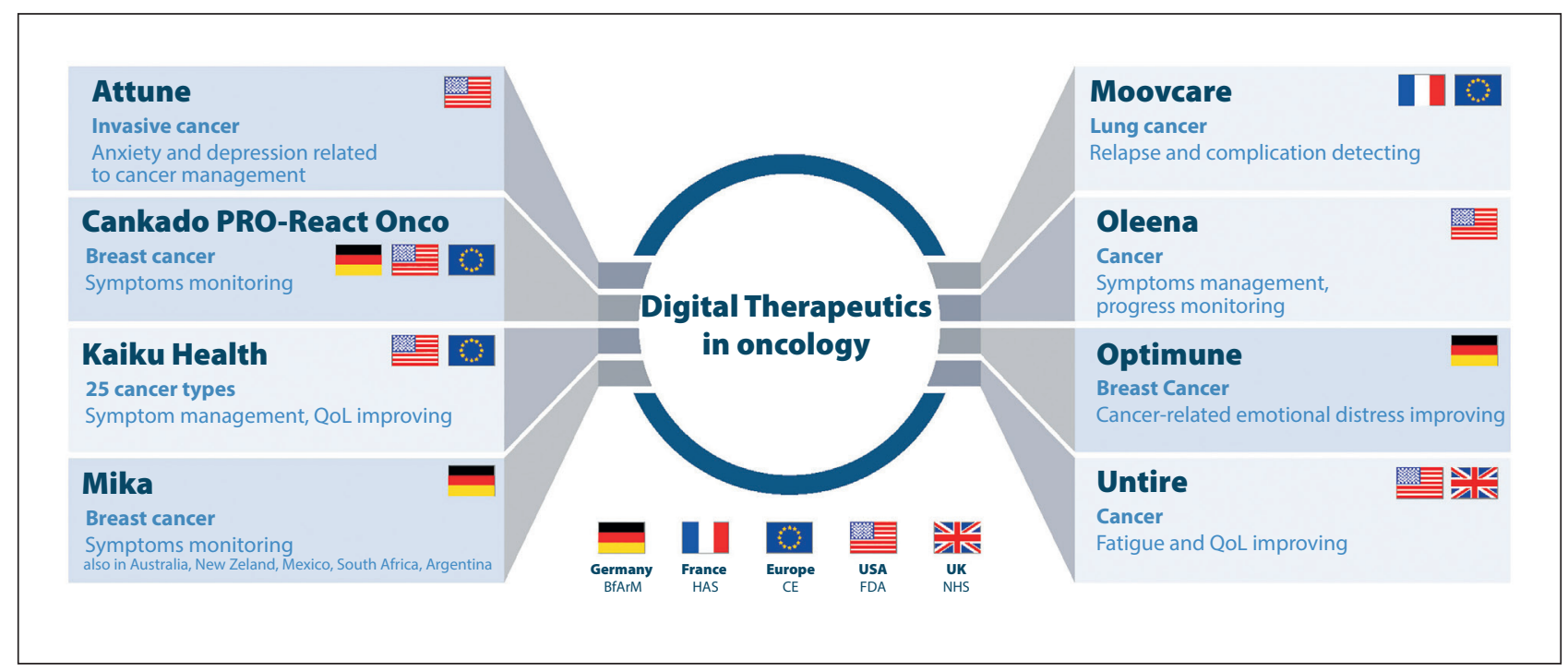

Figure 4. Overview of DTx products with oncological indications. 


\begin{tabular}{|c|c|c|c|c|}
\hline DTx & PAPER & PATIENTS & STUDY DESIGN & RESULTS \\
\hline $\begin{array}{l}\text { Moovcare } \\
\text { Kaiku Health } \\
\text { Oleena }\end{array}$ & $\begin{array}{l}\text { Basch E et al. J } \\
\text { Clin Oncol } 2016 \\
(18)\end{array}$ & $\begin{array}{l}766 \text { patients } \\
\text { during } \\
\text { chemotherapy } \\
\text { for advanced } \\
\text { solid cancer. }\end{array}$ & $\begin{array}{l}\text { RCT-DTx for symptom } \\
\text { monitoring vs conventional } \\
\text { symptom monitoring. } \\
\text { Assessment at } 6 \text { months. } \\
\text { Analysis of survival. }\end{array}$ & $\begin{array}{l}\text { HRQL (measured by the EuroQoL EQ-5D index) } \\
\text { improved in } 34 \% \text { of patients of DTx group vs } 18 \% \\
\text { among controls ( } p<0.001 \text { ). } \\
\text { Significantly lower Emergency Room admission for } \\
\text { patients in the DTx group ( } 34 \% \text { vs } 41 \% ; p=0.02 \text { ). } \\
\text { Patients of the DTx group remained on chemotherapy } \\
\text { longer (mean } 8.2 \text { vs } 6.3 \text { months; } p=0.002 \text { ). } \\
\text { Median OS = } 31.2 \text { months for DTx group vs } 26.0 \\
\text { months for control (difference } 5 \text { months; } p=0.03 \text { ). }\end{array}$ \\
\hline $\begin{array}{l}\text { Moovcare } \\
\text { Kaiku Health } \\
\text { Oleena }\end{array}$ & $\begin{array}{l}\text { Denis F et al. Am } \\
\text { J Clin Oncol } 2017 \\
(32)\end{array}$ & $\begin{array}{l}98 \text { patients with } \\
\text { lung cancer. }\end{array}$ & $\begin{array}{l}\text { Prospective follow-up } \\
\text { using DTx vs conventional } \\
\text { follow-up in historical group } \\
\text { (retrospective). } \\
\text { Median follow-up } 12.3 \\
\text { months in the experimental } \\
\text { arm vs } 16.7 \text { months in the } \\
\text { control group. }\end{array}$ & $\begin{array}{l}\text { Median OS = } 22.4 \text { months for DTx vs } 16.7 \text { months for } \\
\text { control arm ( } p=0.0014) \text {. } \\
\text { One-year survival: } 86.6 \text { for DTx vs } 59,1 \% \text { for controls. }\end{array}$ \\
\hline $\begin{array}{l}\text { Moovcare } \\
\text { Kaiku Health } \\
\text { Oleena }\end{array}$ & $\begin{array}{l}\text { Denis F et al. } \\
\text { JAMA } 2019 \text { (33) }\end{array}$ & $\begin{array}{l}121 \text { patients } \\
\text { with lung } \\
\text { cancer. }\end{array}$ & $\begin{array}{l}\text { RCT - DTx vs routine follow- } \\
\text { up. } \\
\text { Two-year follow-up. }\end{array}$ & $\begin{array}{l}\text { Median OS = } 22.5 \text { months for DTx vs } 14.9 \text { months for } \\
\text { control arm }(p=0.03) \text {. } \\
\text { Performance Status at the first detected relapse was } \\
0-1 \text { for } 75.9 \% \text { of patients in the DTx group vs } 32.5 \% \text { of } \\
\text { controls }(p<0.001) \text {. }\end{array}$ \\
\hline Oleena & $\begin{array}{l}\text { Liu JF et al. JCO } \\
\text { Clin Cancer } \\
\text { Inform } 2018 \text { (34) }\end{array}$ & $\begin{array}{l}16 \text { patients with } \\
\text { ovarian cancer. }\end{array}$ & $\begin{array}{l}\text { Pilot study to test feasibility, } \\
\text { usability and perceived } \\
\text { satisfaction to assist in } \\
\text { managing acute treatment- } \\
\text { related events (hypertension } \\
\text { and diarrhea). }\end{array}$ & $\begin{array}{l}98,2 \% \text { of expected BP values were reported; } 87 \% \text { of } \\
\text { diarrhea events limited to grade } 1 . \\
\text { Hypertension and diarrhea events reported allowed } \\
\text { rapid provider response and a positive overall patient } \\
\text { experience. }\end{array}$ \\
\hline Attune & $\begin{array}{l}\text { Taub CJ et al. } \\
\text { Cancer } 2019 \text { (35) }\end{array}$ & $\begin{array}{l}123 \text { patients } \\
\text { with stage } 0 \text {-IIIb } \\
\text { breast cancer. }\end{array}$ & $\begin{array}{l}\text { RCT - } 3 \text { arms (CBT/RT/ } \\
\text { Control-HE). } \\
\text { 5-week experimental } \\
\text { treatment. } \\
\text { Assessment at } 12 \text { months. }\end{array}$ & $\begin{array}{l}\text { Greater increases in stress management skills (MOCS) } \\
\text { in combined CBT/RT groups vs HE }(p<0.001) \text {. }\end{array}$ \\
\hline Attune & $\begin{array}{l}\text { Penedo FJ et al. } \\
\text { Int J Behav Med } \\
2020 \text { (36) }\end{array}$ & $\begin{array}{l}192 \text { patients } \\
\text { with advanced } \\
\text { prostate cancer. }\end{array}$ & $\begin{array}{l}\mathrm{RCT}-10 \text {-week tablet- } \\
\text { delivered CBSM vs HP. } \\
\text { Assessment at } 12 \text { months. }\end{array}$ & $\begin{array}{l}\text { Changes in HRQOL and symptom burden did not } \\
\text { differ significantly between the groups. Men in } \\
\text { the CBSM group reported greater improvement in } \\
\text { self-reported ability to relax, both groups showed } \\
\text { improvements in cancer-related anxiety and cancer- } \\
\text { related distress }\end{array}$ \\
\hline Untire & $\begin{array}{l}\text { Spahrkas SS et al. } \\
\text { Psychooncology } \\
2020 \text { (37) }\end{array}$ & $\begin{array}{l}799 \text { patients } \\
\text { with cancer- } \\
\text { related fatigue. }\end{array}$ & $\begin{array}{l}\text { RCT 2:1 ratio DTx vs control } \\
\text { group. } \\
\text { Assessment at } 12 \text { weeks. }\end{array}$ & $\begin{array}{l}\text { The DTx group showed greater improvements in } \\
\text { fatigue severity, fatigue interference and overall QoL } \\
\text { on average }(p<0.01) \text {. }\end{array}$ \\
\hline Kaiku Health & $\begin{array}{l}\text { livanainen S et al. } \\
\text { JMIR Form Res } \\
2020 \text { (38) }\end{array}$ & $\begin{array}{l}37 \text { patients } \\
\text { with advanced } \\
\text { cancer treated } \\
\text { with anti- } \\
\text { PD-L(1). }\end{array}$ & $\begin{array}{l}\text { Prospective, one arm study. } \\
\text { Assessment at } 6 \text { months or } \\
\text { until disease progression. }\end{array}$ & $\begin{array}{l}\text { Electronic patient-reported outcome follow-up of } \\
\text { cancer patients receiving ICls is feasible and capture a } \\
\text { wide range of symptoms. }\end{array}$ \\
\hline Kaiku Health & $\begin{array}{l}\text { Schmalz O et al. J } \\
\text { Med Internet Res } \\
2020 \text { (39) }\end{array}$ & $\begin{array}{l}48 \text { respondents } \\
\text { (19 nurses, } \\
8 \text { physicians, } \\
21 \text { patients } \\
\text { with advanced } \\
\text { NSCLC treated } \\
\text { with CIT). }\end{array}$ & $\begin{array}{l}\text { Single arm intervention study } \\
\text { Assessment } 2 \text { months } \\
\text { (interim) and > } 3 \text { months } \\
\text { after use of the DTx. }\end{array}$ & $\begin{array}{l}\text { Most respondents agreed that the tool facilitated } \\
\text { more efficient and focused discussions between } \\
\text { patients and HCPs. } \\
\text { The tool was well integrated into HCP daily clinical } \\
\text { workflow, enabled workflow optimization between } \\
\text { physicians and nurses, and saved time by decreasing } \\
\text { phone consultations and patients visits. }\end{array}$ \\
\hline Optimune & $\begin{array}{l}\text { Holtdirk F et al. } \\
\text { PloS ONE } 2021 \\
(40)\end{array}$ & $\begin{array}{l}363 \text { patients } \\
\text { with breast } \\
\text { cancer. }\end{array}$ & $\begin{array}{l}\text { RCT - Usual care + DTx vs } \\
\text { usual care. } \\
\text { Assessment at } 3 \text { months. }\end{array}$ & $\begin{array}{l}\text { The DTx group obtained significantly better effects on } \\
\text { QoL (WHOQOL-BREF) and dietary habits (FQQ), and a } \\
\text { non significant effect on physical exercise (IPAQ). }\end{array}$ \\
\hline
\end{tabular}

Table I. Studies published as full paper and evaluating DTx products developed for cancer patients.

BP: blood pressure; CIT: cancer immunotherapy; CBSM: cognitive-behavioral stress management; CBT: cognitive behavioral therapy; FQQ: food quality questionnaire; HE: health education; HER2: human epidermal growth factor receptor 2-negative; HP: health promotion; HR+: hormone receptors +; HRQoL: health-related quality of life; ICI: immune checkpoint inhibitor; IPAQ: international physical activity questionnaire; MOCS: measure of current status; NSCLC: non-small cell lung cancer; OS: overall survival; PD-L(1): programmed cell death protein 1- ligand 1; QoL: quality of life; RCT: randomized controlled trial; RT: relaxation training; SAE: serious adverse events. 


\begin{tabular}{|c|c|c|c|c|}
\hline DTx & $\begin{array}{l}\text { DATABASE } \\
\text { IDENTIFIER/ } \\
\text { REFERENCE AND } \\
\text { STATUS }\end{array}$ & PATIENTS & STUDY DESIGN & OBJECTIVES \\
\hline ApricityRx & $\begin{array}{l}\text { NCT04571398 (41) } \\
\text { (Recruiting) }\end{array}$ & $\begin{array}{l}100 \text { patients with cancer, } \\
\text { receiving treatment with } \\
\text { immune-checkpoint } \\
\text { inhibitor. }\end{array}$ & $\begin{array}{l}\text { Observational, prospective cohort } \\
\text { study. } \\
\text { Assessment at } 12 \text { weeks. }\end{array}$ & $\begin{array}{l}\text { Evaluate DTx mobile app to capture and } \\
\text { transmit to care team patient-generated } \\
\text { health data and access education content } \\
\text { on immune-related adverse events and } \\
\text { immuno-oncology therapy. }\end{array}$ \\
\hline ApricityRX & $\begin{array}{l}\text { Campbell MT et al. } \\
\text { J Clin Oncol } 2020 \\
\text { (42) }\end{array}$ & $\begin{array}{l}1000 \text { patients with cancer, } \\
\text { is receiving treatment } \\
\text { with immune-checkpoint } \\
\text { inhibitor alone or in } \\
\text { combination. }\end{array}$ & Single arm, open label study. & $\begin{array}{l}\text { Evaluation of the effectiveness of ApricityRX } \\
\text { as a mitigation strategy for immune-related } \\
\text { adverse events. }\end{array}$ \\
\hline Attune & $\begin{array}{l}\text { NCT04862195 (43) } \\
\text { (Recruiting) }\end{array}$ & $\begin{array}{l}553 \text { patients with stage I-III } \\
\text { breast cancer or stage I-III } \\
\text { non small cell lung cancer. }\end{array}$ & $\begin{array}{l}\text { RCT - to compare the } \\
\text { effectiveness of two DTx (Attune } \\
\text { and Cerena). } \\
\text { Assessment at } 10 \text { and } 12 \text { weeks. }\end{array}$ & $\begin{array}{l}\text { Primary endpoint: improvement in anxiety } \\
\text { symptoms (week 10). } \\
\text { Secondary endpoint: improvement in } \\
\text { depressive symptoms (week 12). }\end{array}$ \\
\hline Attune & $\begin{array}{l}\text { NCT04857008 (44) } \\
\text { (Recruiting) }\end{array}$ & $\begin{array}{l}20 \text { patients with diagnosis } \\
\text { or history of invasive } \\
\text { cancer and mild to } \\
\text { moderate anxiety/ } \\
\text { depression. }\end{array}$ & $\begin{array}{l}\text { Open label (single group), delivery } \\
\text { of cognitive behavioral therapy. } \\
\text { Assessment at } 4 \text { and } 12 \text { weeks. }\end{array}$ & $\begin{array}{l}\text { Identification of promoters and barriers to } \\
\text { clinical implementation. } \\
\text { To measure changes in pre- and post- } \\
\text { cancer-related distress (assessed with the } \\
\text { VSAS / Veterans Symptoms Assessment } \\
\text { Screen tool). }\end{array}$ \\
\hline $\begin{array}{l}\text { CANKADO- } \\
\text { PRO React } \\
\text { Onco }\end{array}$ & $\begin{array}{l}\text { NCT04531995 (45) } \\
\text { (Not-yet recruiting) }\end{array}$ & $\begin{array}{l}166.000 \text { patients with } \\
\text { cancer under systemic } \\
\text { anti-tumor or anti- } \\
\text { hormonal therapy. }\end{array}$ & $\begin{array}{l}\text { Observational (patient registry) } \\
\text { prospective cohort study. } \\
\text { Assessment at } 6 \text { months. }\end{array}$ & 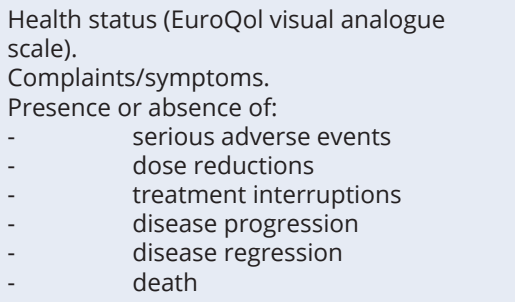 \\
\hline $\begin{array}{l}\text { CANKADO } \\
\text { PRO React } \\
\text { Onco }\end{array}$ & $\begin{array}{l}\text { https://diga. } \\
\text { bfarm.de/de/ } \\
\text { verzeichnis/961 } \\
\text { (46) (Recruiting) }\end{array}$ & $\begin{array}{l}\text { Patients with breast } \\
\text { cancer. }\end{array}$ & $\begin{array}{l}\text { Intervention, comparative vs } \\
\text { conventional management. }\end{array}$ & $\begin{array}{l}\text { Evaluate the effects on general state } \\
\text { of health (EQ-VAS) and patients' } \\
\text { empowerment/health literacy. }\end{array}$ \\
\hline $\begin{array}{l}\text { CANKADO } \\
\text { Pro React } \\
\text { Onco }\end{array}$ & $\begin{array}{l}\text { Degenhardt T et al. } \\
\text { J Clin Oncol } 2020 \\
\text { (47) } \\
\text { (Recruiting) }\end{array}$ & $\begin{array}{l}\text { Patients with } \mathrm{HR}+/ \\
\text { HER2- locally advanced or } \\
\text { metastatic breast cancer. }\end{array}$ & $\mathrm{RCT}$, vs inactive inform arm. & $\begin{array}{l}\text { Evaluate the effects of the digital tool on the } \\
\text { incidence of serious adverse events. } \\
\text { Preliminary unplanned analysis on a } \\
\text { secondary endpoint (primary study } \\
\text { endpoint: QoL). }\end{array}$ \\
\hline Mika & $\begin{array}{l}\text { DRKS00026038 (48) } \\
\text { (Recruiting) }\end{array}$ & $\begin{array}{l}250 \text { adults patients } \\
\text { with malignant tumor } \\
\text { (diagnosis within the last } \\
5 \text { years). }\end{array}$ & $\begin{array}{l}\text { RCT - } 12 \text { weeks Mika-App (+ TAU) } \\
\text { plus } 9 \text { months for an additional } \\
\text { longitudinal follow-up. }\end{array}$ & $\begin{array}{l}\text { Primary endpoint: DT reduction (DT-VAS). } \\
\text { Secondary endpoints: improvement } \\
\text { QoL (CGI-I), fatigue reduction (FACIT-F), } \\
\text { depression/anxiety reduction (HADS-D), } \\
\text { adherence/compliance, patient sovereignty, } \\
\text { health competence. }\end{array}$ \\
\hline Mika & $\begin{array}{l}\text { DRKS00021064 (49) } \\
\text { (Recruiting) }\end{array}$ & $\begin{array}{l}70 \text { adult patients } \\
\text { with cancer receiving } \\
\text { immunotherapy. }\end{array}$ & $\begin{array}{l}\text { RCT - } 12 \text { \& } 24 \text { weeks TAU + SOFIA } \\
\text { / Mika App plus. }\end{array}$ & $\begin{array}{l}\text { Primary endpoint: HRQoL (EORTC QLQ C30). } \\
\text { Secondary endpoints: depression (PHQ9-D); } \\
\text { generalized anxiety disorder (GAD7); } \\
\text { distress (National Comprehensive Cancer } \\
\text { Network/NCCN Distress-Barometer); } \\
\text { supportive care needs (SCNS-SF34-D). }\end{array}$ \\
\hline Mika & $\begin{array}{l}\text { DRKS00022996 (50) } \\
\text { (Recruiting) }\end{array}$ & $\begin{array}{l}524 \text { patients with } \\
\text { malignant tumors. }\end{array}$ & $\begin{array}{l}\text { RCT, standard of care + Mika app } \\
\text { vs standard of care ( } 12 \text { weeks). }\end{array}$ & $\begin{array}{l}\text { Primary endpoint: quality of life. } \\
\text { Secondary endpoints: psychological burden, } \\
\text { psychological stress, fatigue, fear for } \\
\text { progression, health literacy, adherence, self- } \\
\text { management. }\end{array}$ \\
\hline Moovcare & $\begin{array}{l}\text { NCT04934865 (51) } \\
\text { (Not-yet recruiting) }\end{array}$ & $\begin{array}{l}240 \text { patients with lung } \\
\text { cancer. }\end{array}$ & Intervention, single group study. & $\begin{array}{l}\text { Evaluation of the proportion of patients } \\
\text { whose management has been modified at } \\
\text { least once and specially by Moovcare Lung } \\
\text { application at } 12 \text { and } 24 \text { months. }\end{array}$ \\
\hline
\end{tabular}

Table II. Selected clinical studies (planned or ongoing) with DTx products already authorized or under consideration for oncological indications, registered in the database ClinicalTrials.gov or in the German Register of Clinical Studies (accessed January 13, 2022), or presented at ASCO Congresses. DT: psychological distress; HRQoL: health-related QoL; QoL: quality of life; RCT: randomized controlled trial; SOFIA: e-Health application (managing Symptoms OF ImmunotherApy); TAU: therapy as usual. 


\begin{tabular}{|c|c|}
\hline DTx & AVAILABILITY \\
\hline Attune & $\begin{array}{l}\text { USA: class II medical device, only available by prescription. Please note that the } \\
\text { treatment has not been reviewed by the U.S. FDA and is currently the subject of } \\
\text { ongoing clinical trial evaluation. }\end{array}$ \\
\hline $\begin{array}{l}\text { CANKADO (Starter/PRO- } \\
\text { React Onco) }\end{array}$ & $\begin{array}{l}\text { EU: approved class I medical device. } \\
\text { Germany: temporary approval for breast cancer according to DVG. } \\
\text { USA: compliant with the FDA classification for Mobile Medical Devices (2015) } \\
\text { Appendix B. }\end{array}$ \\
\hline Kaiku Health & $\begin{array}{l}\text { EU: CE-marked class lla medical device. } \\
\text { USA: device that falls under the FDA's enforcement discretion. } \\
\text { Australia: class I medical device. } \\
\text { New Zealand, Mexico and South Africa: registered as a medical device. } \\
\text { Argentina: not regulated by medical device regulation. }\end{array}$ \\
\hline Mika & $\begin{array}{l}\text { Germany: transitory approval for cancer/ gynecological cancer (multiple cancer } \\
\text { indications) according to DVG. }\end{array}$ \\
\hline Moovcare & $\begin{array}{l}\text { France: class I medical device / first digital therapy to be approved and reimbursed } \\
\text { by the HAS. } \\
\text { EU: authorized EU representative. }\end{array}$ \\
\hline Oleena & USA: approved as medical device for prescription by FDA. \\
\hline Optimune & Germany: free of charge as part of a scientific study. \\
\hline Untire & $\begin{array}{l}\text { UK: approved by the NHS and listed in the NHS App Library. } \\
\text { UK, USA: ongoing negotiations with insurers and healthcare providers for } \\
\text { reimbursement for cancer fatigue. }\end{array}$ \\
\hline
\end{tabular}

Table III. International regulatory status for DTx products with oncological indications.

DVG: Digitale-Versorgung-Gesetz; EU: European Union; FDA: Food and Drug Administration; HAS: Haute Autorité de Santé; NHS: National Health System; UK: United Kingdom

\section{DISCUSSION}

Digital health technologies offer new opportunities to integrate health promotion, self-care and lifestyle interventions, while simultaneously mitigating limitations of pharmacotherapies such as tolerability, medication nonadherence, or drug resistance. In the specific field of oncology, digital solutions can address certain unmet needs related to better control of symptoms, as well as prevention or management of adverse events in patients with cancer, including: (i) increased communication between patients and healthcare professionals; (ii) education and empowerment of patients and caregivers; (iii) integration of standard clinical assessments with PROs measured during routine clinical practice; (iv) help for patients in monitoring and self-managing their conditions (52). All these opportunities can increase access to treatment, improve the safety and quality of care with better health outcomes, and decrease medical costs $(11,53)$. These benefits, in addition to being evaluated in trials, could be studied in the real world more easily than is the case with drugs, thanks to the opportunities that arise from the use of digital tools.

Among digital health technologies, DTx are evidence-based medical devices aimed at interacting with the patient by providing behavioral and therapeutic indications; there is growing interest for their integration into clinical practice, and this review is focused on products of this category specifically developed for cancer. In this perspective, a first non-trivial point is the risk of misclassification of a digital tool in the category of DTx, as highlighted through a recent systematic review by Santoro et al. (7). This may have influenced our bibliographic search, based on keywords that included the terms "digital therapeutics"/"digital therapies". According- 
ly, our choice for this review was to consider as DTx those products for which at least one randomized controlled trial with confirmatory characteristics was available in the literature or ongoing; or those tools in the active phase of development, as documented by registered ongoing clinical trials and development plan ("candidate DTx"). These criteria excluded a number of digital tools for which information is available online (54-58). Further, we considered the different products' ability to deliver a "therapeutic intervention" (another key aspect for the definition of DTx). This too is a delicate point: for example, the dividing line between DTx and technologies classified as "digital support program" can be a very fine one, particularly in the case of cancer. In fact, the mechanism of action of DTx used in this indication mainly depends on the reaction of healthcare personnel to alerts related to toxicities and symptoms and reported by the patient. Being the digital tool a trigger of the intervention, this can therefore be considered a particular form of "therapeutics". However, for the products selected for this review, the authors considered that their classification as DTx was adequate, in relation both to their disease management purposes and to the presence of an experimental clinical validation program. The mechanisms of action of DTx for cancer patients are generally related to cognitive behavioral stress management, teaching and empowering patients about the significance of key symptoms, vital signs and possibly drug-related adverse events, as well as the real-time reporting of health status and outcomes; and a digital interaction between patients and healthcare personnel that enables the latter to triage, evaluate and treat in a timely fashion. According to the results of available studies, this can lead to improved QoL, physical activity and performance status, as well as of reduced severity of specific symptoms such as fatigue which are particularly common among cancer patients and significantly interfere with their daily activities. These effects were reported in patients with various cancer types, the most frequently represented being breast, lung and prostate cancer. Of particular relevance is the report, documented in some randomized controlled trials, of a significant increase in survival among patients using these digital tools, with orders of magnitude difficult to achieve even through pharmacological therapies of proven efficacy. Once again, potential factors underlying this finding are integration of PROs into the routine care of patients and early responsiveness to patient symptoms, preventing adverse downstream consequences and, where possible, identifying relapses in a timely manner. Moreover, patients receiving the digital intervention were shown to tolerate continuation of chemotherapy longer than usual care (17), and this can contribute to increased survival. Finally, preliminary findings indicate a decreased need for consultations and visits in patients using DTx, thus suggesting a potential benefit in terms of healthcare organization and costs.

The adoption of DTx, both in general and in the specific field of cancer, is complex: it often involves an array of different priorities in various fields, numerous decision-making processes, and individual or organizational value judgments (59). In part, this is believed to be due to the obscurity of the path to market, obstacles in finance and reimbursement, variance in the practice of medicine, regulation and security, and the absence of a structured process surrounding the evaluation and authorization of digital health products (60). Clinician and personal privacy issues, equal access, clinical effectiveness, and safety concerns are also significant potential barriers facing the adoption of DTx (61). A crucial point in meeting these concerns is, first of all, the value of the clinical benefit that DTx can bring, starting from the evidence provided by clinical studies; in other words, how to guarantee adequate, uniform efficacy and safety standards, similar to those for drugs used in the same therapeutic indication. While recognizing that the risk of obsolescence necessitates rapid lead times for DTx development, that their peculiarities must be taken into account at the study design phase, and that different types of studies (e.g. observational, or interventional single arm) may be useful for definition of the product's profile, randomized controlled trials represent the ideal model for pivotal clinical investigation of DTx. These must be carried out on an adequately sized sample (particularly in confirmatory studies), so that significant effects can be statistically demonstrated and be satisfactory for clinicians, Regulatory Authorities and possible other payers. In this perspective, some limits still exist for DTx specifically developed for cancer indications, and this was reflected in our literature review. The number of randomized controlled trials is low, and that of studies with a pre-defined and statistically adequate sample size is even lower. Further, it is not clear in how many of these studies the definition of the design and the objectives benefited from the active participation of patients, an aspect that is probably even more critical for DTx than for traditional pharmacological therapies. In addition, publication 
bias cannot be ruled out, since there are appreciably fewer published papers than there are studies registered in international databases (e.g. ClinicalTrials.gov). These are crucial issues that need to be addressed, in order to favor a more substantial and evidence-based place of DTx in therapy of oncological indications.

On the other hand, the data available in the literature seem to indicate the prospect of a useful role for digital tools in addressing the many unmet needs that characterize the current management of cancer patients. The promising findings on patient-reported outcomes/QoL, symptoms and overall survival lend weight to the view that a digitally supported and systematic engagement of patients can plausibly lead to better chronic control of the disease and improved outcomes. Our review was focused on the results obtained by digital products specifically developed for cancer indications, but we must not forget that in many countries a number of extensively studied and widely used digital tools (including DTx) are already available, with indications for clinical conditions frequent in cancer patients (e.g., depression, insomnia, abuse of opioids).

Important progress towards a place in therapy for DTx in oncology is being achieved, but this has been the case only in the last few years. The road ahead is therefore still long, demanding and challenging, especially considering the enormous impact of cancer on the population and on public health resources. One of the major challenges is - and will continue to be - the effective application of virtual care models for cancer survivorship, in order to support patients living with the chronic effects of cancer treatment while also increasing health care capacity and sustainability (62). The ideal digital solution in the setting of supportive care in oncology would be user-friendly, intuitive, and engaging, so as to meet the immediate needs of the end-users. It would not be meant as a replacement for the practitioner, but as an efficient source of real-time complementary information, appropriate to the care of cancer patients and the specific related issues. Sufficiently detailed but not over-complicated, this information would be presented in language the patient understands, with a view to achieving effective symptom self-management (63). The digital solution would maintain existing expectations regarding patient confidentiality and data privacy (64), cybersecurity, compliance with regulatory requirements, and alignment with the most recent evidence-based practice. It would be operational throughout the entire course of the disease and for the range of different anti-cancer treatments, as well as sufficiently flexible for adaptation to different territories, settings and care needs (11).

It is likely that DTx will demonstrate their strengths in the current and future medical scenario, increasingly enabling the healthcare system to deliver personalized and customized medical care. However, apart from how well DTx are developed (and this is the most important point), their success and broad-based adoption is linked to overcoming a series of significant issues: need for strong evidence of clinical benefit on relevant outcomes/endpoints; difficulties in getting physicians to indicate and prescribe DTx due to lack of familiarity with these technologies; perceived difficulty in use; absence of standards and of a consolidated process for providing prescriptions; reimbursement arrangements; regulatory systems; and access to technology and improved digital literacy for patients and caregivers. As previously pointed out, clinical validation is a crucial point for DTx. The development of these products could benefit from a greater specific digital and methodological competence of researchers, including Health Technology Assessment. The latter, together with the recognition as an innovative product, is a critical dimension of the regulatory path also for the DTx, especially for healthcare contexts in which publicly funded assistance prevails, and the DTx aspire to reimbursement.

The awareness and engagement of patients is of paramount importance for the success of DTx, and in this perspective a fundamental role could be played by patient organizations. But one of the most important aspects that must be governed for an effective implementation of DTx in clinical practice concerns their management by healthcare personnel. Resources needed for the success of DTx are not only on the side of software, hardware and connection to the Internet, but also in terms of human resources and availability of time (i.e., nurses and physicians who monitor collection of data and react to alerts). If this issue is not successfully addressed, and the DTx fail to be integrated into the normal care pathways, their ability to effectively intervene on the quality of life and clinical outcomes of patients, risks being significantly compromised.

This means that all stakeholders - governments, health systems, digital therapy entrepreneurs, pharmaceutical companies, payers, providers, researchers, physicians and patients - must agree on a common model. Only in this way will it prove 
possible to define, develop, evaluate from the clinical evidence standpoint, commercialize, and distribute these products in line with adequate standards. This will make it possible to improve patient health and wellbeing, potentially decrease medical costs, and ensure widespread access to these products in a safe and effective manner. More clinical research, in terms of large-scale trials, and related systematic reviews and meta-analyses, could help significantly with a view to reaching these goals.

\section{ACKNOWLEDGMENTS}

The authors would like to thank Peter Gordon Mead for his careful linguistic revision of the manuscript.

\section{ETHICS}

\section{Fundings}

There were no institutional or private fundings for this article.

\section{REFERENCES}

1. Gussoni G. Executive summary. In Gussoni G. (Editor) Digital therapeutics: an opportunity for Italy, and beyond. Passoni Editor, Milan, Italy, 2021.

2. Digital Therapeutics Alliance, Digital Therapeutics: Combining Technology and Evidence-based Medicine to Transform Personalized Patient Care. Available from: https:// dtxalliance.org/wp-content/uploads/2018/09/ DTA-Report_DTx-Industry-Foundations.pdf. Last accessed: Dec 7, 2021).

3. Digital Therapeutic Alliance. Digital Health, Digital Medicine, Digital Therapeutics (DTx): what's the Difference? Available from: https://dtxalliance.org/2019/11/11/digital-health-digital-medicine-digital-therapeutics-dtx-whats-the-difference/. Last accessed: Dec 7, 2021.

4. Sverdlov O, van Dam J, Hannesdottir K, Thornton-Wells T. Digital therapeutics: an integral component of digital innovation in drug development. Clin Pharmacol Ther 2018;104(1):72-80.

5. Da Ros L, Recchia G, Gussoni G. Why a volume on digital therapeutics, and not just for Italy. In

\section{Conflict of interests}

ER and MZ are employers at Healthware Group; GR is CEO at daVI DigitalMedicine srl which signed a joint partnership with Polifarma SpA for research and marketing of digital medical devices; FP received institutonal grant for research activities from AstraZeneca, Bayer, BioClin, Incyte, Jannsen, Merck, Pfizer, Roche, Sanofi, Tesaro and honoraria for educational or advisory activity from Astellas, AstraZeneca, Bayer, Clovis, Incyte, Ipsen, Jannsen, Pierre Fabre, Roche, Sanofi; GG, ES and RA have declared no conflict of interests.

\section{Availability of data and materials}

No new data associated with this article.

\section{Authors' contribution}

Conception and design of the work: GG. Acquisition, analysis and interpretation of data for the work: GG, ER, MZ. Drafting the article: GG, ER, MZ. Revising the article critically for important intellectual content: GR, ES, RA, FP. Provide approval for publication of the content: all the authors.

\section{Ethical approval}

N/A.

Digital therapeutics: an opportunity for Italy, and beyond. Passoni Editor, Milan, Italy, 2021.

6. Hong JS, Wasden C, Han DH. Introduction of digital therapeutics. Comput Methods Programs Biomed 2021;209:106319.

7. Santoro E, Boscherini L, Caiani E. Digital therapeutics: a systematic review of clinical trials characteristics. European Society of Cardiology 2021 Congress. Available from: https:// esc2021-abstract.medicalcongress.online/mediatheque/share. aspx?channel=103467\&mediald=106780. Last accessed: Feb 21, 2022.

8. Allemani C, Matsuda T, Di Carlo V, Harewood R, Matz M, Niksic M, et al; CONCORD Working Group. Global surveillance of trends in cancer survival 2000-14 (CONCORD-3): analysis of individual records for 37513025 patients diagnosed with one of 18 cancers from 322 population-based registries in 71 countries. Lancet 2018;391:1023-75.

9. Beaton L, Bandula S, Gaze MN, Sharma RA. How rapid advances in imaging are defining the future of precise radiation oncology. $\mathrm{Br} J$ 
Cancer 2019;120:779-90.

10. Kaufman HS, Atkins MB, Subedi $P$, et al. The promise of immuno-oncology: implications for defining the value of cancer treatment. J Immunother Cancer 2019;7:129.

11. Aapro M, Bossi P, Dasari A, Fallowfield L, Gascon P, Geller M, et al. Digital health for optimal supportive care in oncology: benefits, limits and future perspectives. Support Care Cancer 2020;28:4589-612.

12. Partridge AH, Wang PS, Winer EP, Avon J. Nonadherence to adjuvant tamoxifen therapy in women with primary best cancer. J Clin Oncol 2003;21:602-6.

13. McCarthy PL, Holstein SA, Petrucci MT, Richardson PG, Hulin C, Tosi P, et al. Lenalidomide maintenance after autologous stem-cell transplantation in newly diagnosed multiple myeloma: a meta-analysis. J Clin Oncol 2017:35:3279-89.

14. American Society of Clinical Oncology. The state of cancer care in America, 2016: a report by the American Society of Clinical Oncology, 2016. Available from: https://doi.org/10.1200/ jop.2015.010462. Last accessed: Dec 8, 2021.

15. Jordan K, Aapro M, Kaasa S, Ripamonti Cl, Scotte' F, Strasser F, et al. European Society for Medical Oncology (ESMO) position paper on supportive and palliative care. Ann Oncol 2018;29:36-43.

16. Kaasa $\mathrm{S}$, Loge JH, Aapro M, Albreht T, Anderson $R$, Bruera $E$, et al. Integration of oncology and palliative care: a Lancet Oncology Commission. Lancet Oncol 2018;19:e588-e653.

17. Basch E, Deal AM, Dueck AC, Scher HI, Kris MG, Hudis C, Schrag D. Overall survival results of a trial assessing patient-reported outcomes for symptom monitoring during routine cancer treatment. JAMA 2017;318: 197-8.

18. Basch E, Deal AM, Kris MG, Scher HI, Hudis CA, Sabbatini $P$, et al. Symptom monitoring with patient-reported outcomes during routine cancer treatment: a randomized controlled trial. J Clin Oncol 2016;34:557-65.

19. Ferlay J, Soerjomataram I, Dikshit R, Eser S, Mathers $C$, Rebelo $M$, et al. Cancer incidence and mortality worldwide: sources, methods and major patterns in GLOBOCAN 2012. Int J Cancer 2015;136:E359-E386.

20. Cook R. Economic and clinical impact of multiple myeloma to managed care. J Manag Care Pharm 2008;14:19-25.

21. Yang J, Weng L, Chen Z, Cai H, Lin X, Hu Z, et al. Development and testing of a mobile app for pain management among cancer patients discharged from hospital treatment: randomized controlled trial. JMIR Mhealth Uhealth 2019;7(5):e12542.

22. Kim HJ, Kim SM, Shin H, Jang JS, Kim Yl, Han DH. A mobile game for patients with breast cancer for chemotherapy self-management and quality-of-life improvement: randomized controlled trial. J Med Internet Res 2018;20(10):e273.

23. Fjell $M$, Langius-Eklof $A$, Nilsson $M$, Wengstrom $Y$, Sundberg K. Reduced symptom burden with the support of an interactive app during neoadjuvant chemotherapy for breast cancer - a randomized controlled trial. The Breast 2020;51:85-93.

24. Govender M, Bowen RC, German ML, Bulaj G, Bruggers CS. Clinical and neurobiological perspectives of empowering pediatric cancer patients using videogames. Games Health J 2015; 4(5):362-74.

25. Bruggers CS, Baranowski S, Beseris M, Leonard $\mathrm{R}$, Long $\mathrm{D}$, Schulte $\mathrm{E}$. A prototype exercise-empowerment mobile video game for children with cancer, and its usability assessment: developing digital empowerment interventions for pediatric diseases. Front Pediatr 2018;6:69.

26. Henry DH, Viswanathan HN, Helkin EP, Traina S, Wade S, Cella D. Symptoms and treatment burden associated with cancer treatment. Results from a cross-sectional national survey in the U.S. Support Care Cancer 2008;16:791-801.

27. Fromme EK, Eilers KM, Mori M, Hsieh YC, Beer TM. How accurate is clinician reporting of chemotherapy adverse effects? A comparison with patient-reported symptoms with the Quality-of-Life questionnaire C30. J Clin Oncol 2004;22:3485-90.

28. Basch $E$, lasonos A, McDonough T, Barz A, Culkin A, Kris MG, et al. Patient versus clinician symptom reporting using the National Cancer Institute Common Terminology Criteria for Adverse Events: results of a questionnaire-based study. Lancet Oncol 2006;7:903-9.

29. Laugsand EA, Sprangers MA, Bjordal K, Skorpen F, Kaasa S, Klepstad P. Health care providers underestimate symptom intensities of cancer patients. A multicenter European study. Health Qual Life Outcomes 2010;8:104.

30. Available from: https://apricity-health.com. Last accessed: Feb 21, 2022.

31. Available from: https://www.businesswire.com/ news/home/20200113005185/en/Pear-Therapeutics-Announces-Collaboration-with-Apricity-Health-to-Advance-Prescription-Digital-Therapeutics-to-be-Prescribed-in-Combi- 
nation-with-Immuno-oncology-Therapy. Last accessed: Feb 21, 2022.

32. Denis F, Yossi S, Septans AL, Charron A, Voog E, Dupuis $O$, et al. Improving survival in patients treated for a lung cancer using self-evaluated symptoms reported through a web application. J Am Clin Oncol 2017;40:464-9.

33. Denis F, Basch E, Septans AL, Bennouna J, Urban T, Dueck AC, et al. Two-year survival comparing web-based symptom monitoring vs routine surveillance following treatment for lung cancer. JAMA 2019;321:306-7.

34. Liu JF, Lee JM, Strock E, Phillips R, Mari K, Killiam $B$, et al. Technology applications: use of digital health technology to enable drug development. JCO Clin Cancer Inform 2018;2:1-12.

35. Taub CJ, Lippman ME, Hudson Bl, Blomberg BB, Diaz A, Fisher HM, et al. The effects of a randomized trial of brief forms of stress management on RAGE-associated S100A8/A9 in patients with breast cancer undergoing primary treatment. Cancer 2019;125:1717-25.

36. Penedo FJ, Fox RS, Oswald LB, Moreno PI, Boland $\mathrm{CL}$, Estabrook R, et al. Technology-based psychosocial intervention to improve quality of life and reduce symptom burden in men with advanced prostate cancer: results from a randomized controlled trial. Int J Behav Med 2020;27:490-505.

37. Spahrkas SS, Looijmans A, Sanderman R, Hagedoorn M. Beating cancer-related fatigue with the Untire mobile app: results from a waiting-list randomized trail. Psychooncology 2020;29:1823-34.

38. livanainen $S$, Alanko $T$, Vihinen $P$, Konkola $T$, Ekstrom J, Virtanen $\mathrm{H}$, et al. Follow-up of cancer patients receiving anti-PD-L(1) therapy using an electronic patient-reported outcomes tools (KISS): prospective feasibility cohort study. JMIR Form Res 2020;4:e17898.

39. Schmalz O, Jacob C, Ammann J, Liss B, livanainen $\mathrm{S}$, Kammermann $\mathrm{M}$, et al. Digital monitoring and management of patients with advanced or metastatic non-small cell lung cancer treated with cancer immunotherapy and its impact on quality of clinical care: interview and survey among health care professionals and patients. J Med Internet Res 2020;22:e18655.

40. Holtdirk F, Mehnert A, Weiss M, Mayer J, Meyer $B$, Brode $P$, et al. Results of the Optimune trial: a randomized controlled trial evaluating a novel Internet intervention for breast cancer survivors. PloS ONE 2021;16:e0251276.

41. Available from: https://clinicaltrials.gov/ct2/show/
NCT04571398. Last accessed: Feb 21, 2022.

42. Campbell MT, Zhang T, Chin L, Betof Warner A, Mathew M. ApricityRx companion digital therapeutic for evidence-based mitigation and phenotype-linked molecular characterization of irAEs in patients receiving immune checkpoint therapy (ICT). J Clin Oncol 2020; 38(15) Suppl:TPS2089.

43. Available from: https://clinicaltrials.gov/ct2/show/ NCT04862195. Last accessed: Feb 21, 2022.

44. Available from: https://clinicaltrials.gov/ct2/show/ NCT04857008. Last accessed: Feb 21, 2022.

45. Available from: https://clinicaltrials.gov/ct2/show/ NCT04531995. Last accessed: Feb 21, 2022.

46. Available from: https://diga.bfarm.de/de/verzeichnis/961. Last accessed: Feb 21, 2022.

47. Degenhardt T, Harbeck N, Fasching PA, Wuerstlein R, Lüftner D, Kates RE, et al. Documentation patterns and impact on observed side effects of the CANKADO ehealth application: An exploratory analysis of the PreCycle trial. J Clin Oncol 2020;38(15) Suppl:2083.

48. Available from: https://www.drks.de/drks_web/ navigate.do?navigationld=trial. $H T M L \& T R I A L$ ID=DRKS0002603. Last accessed: 21 Feb, 2022.

49. Available from: https://www.drks.de/drks_web/ navigate.do?navigationld=trial.HTML\&TRIAL_ ID=DRKS00021064. Last accessed: 21 Feb, 2022.

50. Available from: https://www.drks.de/drks_web/ navigate. do?navigationld=trial. HTML\&TRIAL_ ID=DRKS00022096. Last accessed: 21 Feb, 2022.

51. Available from: https://clinicaltrials.gov/ct2/show/ NCT04934865. Last accessed: 21 Feb, 2022.

52. Kruse CS, Goswamy R, Raval Y, Marawi S. Challenges and opportunities of big data in health care: a systematic review. JMIR Medical Inform 2016;4:e38.

53. Kolb NA, Smith AG, Singleton JR, Beck SL, Howard D, Dittus K, et al. Chemotherapy-related neuropathic symptom management: a randomized trial of an automated symptom-monitoring system paired with nurse practitioner follow-up. Support Care Cancer 2018;26:1607-15.

54. Available from: https://www.tavie. health/2019/05/31/360medlink-announcesthe-first-cancer-indication-for-its-tavie-virtualcoach-platform/. Last accessed: 21 Feb, 2022.

55. Available from: https://www.lifesemantics.kr/ service/redpillCare. Last accessed: 21 Feb, 2022.

56. https://www.statnews.com/2019/01/17/adigital-pill-for-cancer-patients-is-rolled-outfor-the-first-time-in-hopes-of-improving-outcomes/. Last accessed: 21 Feb, 2022. 
57. Available from: https://itkey.media/prosomaaims-to-speed-up-digital-therapeutics-adoption-hopes-to-break-into-german-market-bythe-end-of-2021/. Last accessed: 21 Feb, 2022.

58. Available from: https://www.neurotrackerx.com/ post/qa-with-professor-faubert-on-the-future-ofdigital-health. Last accessed: 21 Feb, 2022.

59. Greenhalgh T, Wherton J, Papoutsi C, Lynch J, Hughes G, A'Court C, et al. Beyond adoption: a new framework for theorizing and evaluating nonadoption, abandonment, and challenges to the scale-up, spread, and sustainability of health and care technologies. J Med Internet Res 2017;19:e367.

60. Steinhubl SR, Muse ED, Topol EJ. The emerging field of mobile health. Sci Transl Med 2015;7(283):283rv3.
61. Coopey M, James MD, Lawrence W, Clancy CM. The challenge of comparative effectiveness: getting the right information to the right people at the right time. J Nurs Care Qual 2008;23:1-5.

62. Pham Q, Hearn J, Gao B, Brown I, Hamilton RJ, Berlin A, et al. Virtual care models for cancer survivorship. npj Digit Med 2020;3:113.

63. Atena $\mathrm{V}$, van Leeuwen $M$, Oldenburg HSA, van Beurden M, Hunter MS, Aaronson MH. An Internet-based cognitive behavioral therapy for treatment-induced menopausal symptoms in breast cancer survivors: results of a pilot study. Menopause 2017;24:762-7.

64. Alberts NM, Hadjistavropoulos HD, Dear BF, Titov N. Internet-delivered cognitive-behavior therapy for recent cancer survivors: a feasibility trial. Psychooncology 2017;26:137-9. 